\title{
Hepatitis C virus infection in Jordanian haemodialysis units: serological diagnosis and genotyping
}

\author{
SALWA BDOUR \\ Department of Biological Sciences, Faculty of Science, University of Jordan, Amman, Jordan
}

\begin{abstract}
The seroprevalence and genotypes of hepatitis C virus (HCV) were studied in 283 patients attending six haemodialysis units in Jordan. In all, 98 (34.6\%) patients were anti-HCV-positive by EIA, $92(93.9 \%)$ of whom were also reactive in an immunoblot assay. The prevalence of anti-HCV was correlated with a history of blood transfusion before the introduction of blood donor screening for $\mathrm{HCV}$ and with duration of haemodialysis. HCV RNA was detected in $30(30.6 \%)$ of 98 anti-HCV-positive sera. HCV viraemia was not associated with a particular antibody for the six HCV antigens studied by the immunoblot assay, although reactivity to the core antigens was greater in the HCV RNA-positive sera than in negative sera. Two HCV genotypes ( 1 and 4 ) were identified for the first time in Jordan by restriction fragment length polymorphism analysis of HCV $5^{\prime}$-NCR. The predominant genotype was HCV 1 a (12 of 30). Genotypes $1 \mathrm{~b}$ and 4 were detected in 10 and 8 patients, respectively. The antibody response to $\mathrm{HCV}$ antigens was genotype-dependent, with a wider range of antibody specificities detected in the immunoblot assay in the 12 patients with genotype 1a infection than in the 8 patients with genotype 4 . However, there was no significant difference in the prevalence of antibodies to $\mathrm{HCV}$ antigens among patients infected with either genotype 1a or $1 \mathrm{~b}$. In conclusion, the prevalence of anti-HCV, blood transfusion, duration of dialysis and $\mathrm{HCV}$ genotypes suggest possible nosocomial HCV transmission among patients which needs confirmation by phylogenetic analysis of subgenomic $\mathrm{HCV}$ regions.
\end{abstract}

\section{Introduction}

Haemodialysis patients have a high risk of acquiring hepatitis $\mathrm{C}$ virus (HCV) infection. Transfusion of unscreened blood [1], duration of dialysis [2] and nosocomial transmission within haemodialysis units [3, 4] are implicated as the main transmission routes of $\mathrm{HCV}$ in haemodialysis patients. In these patients, HCV infection is usually asymptomatic [5] and can be diagnosed by serological methods and by amplification of HCV RNA by reverse transcriptase-PCR (RT-PCR) [6], which distinguishes between viraemic and nonviraemic $\mathrm{HCV}$ patients and also is used for $\mathrm{HCV}$ genotyping [7]. HCV isolates have been classified into six major genotypes, many of which contain a number of closely related subtypes [8]. New HCV variants from Vietnam, Jakarta and Indonesia have been

Received 3 Sept. 2001; revised version accepted 11 March 2002.

Corresponding author: Dr S. Bdour (e-mail: bsalwa@ sci.ju.edu.jo). described as genotypes 7, 8, 9, 10 and 11 [9-10]. The distribution of HCV genotypes varies in different countries as documented in blood donors, and haemodialysis and chronic hepatitis patients [11-13]. There has been no report on HCV genotypes in Jordan. Therefore, this study used both serological and molecular methods to assess (i) the prevalence of anti-HCV and HCV RNA among haemodialysis patients in different dialysis units in Jordan, (ii) the influence of blood transfusion and dialytic age on $\mathrm{HCV}$ infection, (iii) the HCV genotypes and (iv) the correlation between HCV genotypes, viraemia and the antibody response to various HCV antigens.

\section{Materials and methods}

\section{Patients}

In all, 283 patients from haemodialysis units at six government hospitals were studied, with informed, written consent. Plasma samples were separated from 
the whole blood within $1-3 \mathrm{~h}$ of vein puncture, divided into small volumes and stored at $-70^{\circ} \mathrm{C}$.

Information on the age of patients, duration of haemodialysis, number of blood transfusions and renal diagnosis was obtained from patient records and interviews. The renal diagnoses were: chronic renal failure and hypertension $(\mathrm{n}=81)$, chronic glomerulonephritis (46), diabetic nephropathy (42), small kidney (33), failed kidney transplant (12), polycystic kidney (6) and others (63).

\section{Biochemical tests}

Serum alanine aminotransferase (ALT) and aspartate aminotransferase (AST) levels were measured by spectrophotometry with kits from Menagent (Italy) according to the manufacturer's instructions.

\section{Serology}

All plasma samples were tested by the Innotest $\mathrm{HCV}$ Ab IV (Innogenetics, Belgium) enzyme immunoassay (EIA) for the presence of antibodies against proteins derived from four regions of the $\mathrm{HCV}$ genome: core, NS3, NS4 and NS5. EIA-positive samples were retested by the Inno-EIA HCV Ab III immunoblot system (Innogenetics), according to the manufacturer's instructions. Each strip incorporates $\mathrm{HCV}$ antigens derived from the core $(\mathrm{C} 1, \mathrm{C} 2), \mathrm{E} 2, \mathrm{NS} 3, \mathrm{NS} 4 \mathrm{~A}, \mathrm{NS} 4 \mathrm{~B}$ and NS5 regions.

\section{Reverse transcriptase nested PCR (RT-nested PCR)}

RNA was extracted from $200-400 \mu$ of all seropositive plasma samples with the commercially available high pure RNA Kit (Boehringer Mannheim, Germany). To detect contamination, an HCV-negative plasma was extracted with each batch of five RNA extractions.
Extracted RNA was reverse transcribed and amplified with nested primers matching the conserved sequences in the $5^{\prime}$ non-coding region (5'-NCR) of HCV RNA [14]. A negative PCR blank with distilled water instead of RNA was included with each set of five reactions. The PCR products $(5 \mu \mathrm{l})$ were subjected to electrophoresis in agarose (Promega, USA) 3\% and the band size was assessed by direct comparison with a 100-bp DNA marker (Promega).

\section{Genotyping analysis}

HCV genotypes were determined by restriction fragment length polymorphism (RFLP) analysis of the 5'-NCR. The positive RT-nested PCR products were digested separately by two pairs of restriction endonucleases (HaeIII/RsaI and MvaI/HinfI; Boehringer Mannheim) for differentiation into genotypes 1-6 [15]. Subtypes 1a/ $\mathrm{c}$ and $1 \mathrm{~b}$ were further differentiated by digestion with the restriction endonuclease Bst $\mathrm{UI}$ (New England Biolabs, USA). Band size was assessed by direct comparison with a 20-bp DNA marker (BioRad, USA).

\section{Statistical analysis}

The $\chi^{2}$ test was used for statistical analysis, with Fisher's exact test where any one value was $<5$; $p$ values $<0.05$ were considered significant. Correlation coefficients were determined with an Excel programme.

\section{Results}

In all, 174 male and 109 female patients aged 9-80 years were enrolled into the study (Table 1). Sera from 98 patients $(34.6 \%)$ were anti-HCV positive. Seropositivity rates did not differ between male $(36.8 \%)$ and female $(31.2 \%)$ patients. The duration of haemodialysis treatment was grouped into $<12,12-48$ and $>48$ months. Rates of anti-HCV seropositivity were corre-

Table 1. Characteristics of haemodialysis patients tested by EIA

\begin{tabular}{|c|c|c|c|}
\hline \multirow[b]{2}{*}{ Parameter } & \multicolumn{3}{|c|}{ Number $(\%)$ of patients } \\
\hline & $\begin{array}{c}\text { Total } \\
(\mathrm{n}=283)\end{array}$ & $\begin{array}{l}\text { Anti-HCV-positive } \\
\quad(\mathrm{n}=98)\end{array}$ & $\begin{array}{l}\text { Anti-HCV-negative } \\
\quad(\mathrm{n}=185)\end{array}$ \\
\hline \multicolumn{4}{|l|}{ Sex } \\
\hline Male & 174 & $64(36.8)$ & $110(63.2)$ \\
\hline Female & 109 & $34(31.2)$ & $75(68.8)$ \\
\hline \multicolumn{4}{|c|}{ Duration of haemodialyis (months) } \\
\hline$<12$ & 45 & $3(6.7)$ & $42(93.3)$ \\
\hline $12-48$ & 135 & $27(20)$ & $108(80)$ \\
\hline$>48$ & 103 & $68(66)$ & $35(34)^{*}$ \\
\hline Previous blood transfusion & 191 & $62(32.5)$ & $129(67.5)$ \\
\hline before 1993 & 16 & $11(68.7)$ & $5(31.3)$ \\
\hline after 1993 & 175 & $51(29.2)$ & $124(70.8)^{*}$ \\
\hline \multicolumn{4}{|l|}{ Elevated } \\
\hline ALT & 7 & $6(85.7)$ & $1(14.3)$ \\
\hline AST & 7 & $5(71.4)$ & $2(28.8)$ \\
\hline
\end{tabular}

${ }^{*} \mathrm{p}<0.001$ for $<12$ months dialysis versus $>48$ months, and for receipt of blood transfusion before and after 1993 . 
lated with the duration of haemodialysis $\left(\mathrm{r}^{2}=0.988\right)$. The prevalence of anti-HCV in those who had undergone haemodialysis for $>48$ months was significantly higher than in those who had undergone dialysis for $<48$ months $(\mathrm{p}<0.001)$. In Jordan, anti-HCV screening was introduced to blood banks in 1993. The prevalence of anti-HCV was significantly higher in patients who received blood transfusion before 1993 $(68.7 \%)$ than those who received blood transfusion after $1993(29.2 \%, \mathrm{p}<0.001)$. Only six $(6.1 \%)$ and five (5.1\%) of anti-HCV positive patients had elevated ALT and AST levels, respectively.

Variation in the prevalence of anti-HCV was observed between the haemodialysis units (range 13.6-47.1\%) (Table 2).

HCV RNA was detected in $30(30.6 \%)$ of the 98 antiHCV-positive patients, with the prevalence of $\mathrm{HCV}$ RNA varying from $0 \%$ to $41.6 \%$ in the six dialysis units.

In 92 of 98 anti-HCV EIA-positive sera, the result was confirmed by immunoblot; 29 of these sera were HCV RNA-positive. Four sera gave indeterminate results on immunoblotting (one was HCV RNA-positive) and two were negative (one was HCV RNA-positive).

There were no significant differences in the prevalence of antibodies to different HCV antigens between HCV RNA-positive and HCV RNA-negative sera. However, HCV RNA-positive sera were more likely to have high intensity antibody bands $(3+$ or $4+)$ to core antigens (C1 20/30 versus 10/68, C2 17/30 versus 9/68; $\mathrm{p}<0.001)$ than HCV RNA-negative sera.

The predominant HCV genotype was 1a, detected in $40 \%$ of HCV RNA-positive patients, whilst genotypes $1 \mathrm{~b}$ and 4 were found in $33.3 \%$ and $26.6 \%$ of patients, respectively. All isolates from patients in Unit 3 were genotype 1 (Table 2).

Patients infected with genotype 1a were more likely than those infected with type 4 to have detectable antibodies in the immunoblot assay to core $1(12 / 12$ versus $5 / 8, \mathrm{p}=0.049), \mathrm{E} 2(10 / 12$ versus $3 / 8$, $\mathrm{p}=0.06)$, NS4 $(11 / 12$ versus $2 / 8, \mathrm{p}=0.004)$ and
NS5 $(6 / 12$ versus $0 / 8, p=0.04)$ antigens. There were no other significant differences in antibody distribution between patients with genotypes $1 \mathrm{a}, 1 \mathrm{~b}$ or 4 .

\section{Discussion}

This is the first study to report on the seroprevalence and genotyping of $\mathrm{HCV}$ in haemodialysis patients in Jordan. The seroprevalence of $34.6 \%$ compares with $41.9 \%$ in Saudi Arabia [16], 45\% in Tunisia [17] and $45 \%$ in Syria [18]. HCV RNA was detected in only $30.6 \%$ of anti-HCV positive patients (Table 2). Possible explanations for this low percentage of viraemic patients include (i) false positive serology, (ii) intermittent viraemia, (iii) unusually high rates of clearance of infection in these dialysis patients or (iv) levels of viraemia in these patients below the lower limit of detection of the genome detection assay. The low rates of strong positive $(3+$ or $4+)$ antibody bands in the immunoblot assay in the HCV RNA-negative sera support the first hypothesis. however, it has also been reported that $7-68 \%$ of haemodialysis patients have intermittent viraemia with periods of undetectable HCV RNA for up to 4 weeks [7, 19-21]. The viral load is relatively low in this group of patients and long-term maintenance haemodialysis decreases the HCV RNA level but does not produce clearance of viraemia [22-24]. It is not possible to discern for certain which of the four suggested hypotheses pertains in this group of patients.

$\mathrm{HCV}$ viraemia was not associated with a particular antibody specificity, as also reported elsewhere [25, 26]. In contrast, others have reported that antibodies to capsid antigen (C22) [27] or NS3 region [28] are more likely to be correlated with viraemia. However, in the present study, HCV RNA was associated with stronger reactivity $(3+, 4+)$ to $\mathrm{HCV}$ core $(\mathrm{C} 1, \mathrm{C} 2)$ antigens in the immunoblot assay, as compared with the HCV RNA-negative sera.. The low reactivity $(1+)$ to $\mathrm{C} 1$ and $\mathrm{C} 2$ in HCV RNA-negative patients suggests resolved infection with loss of antibodies. Such a profile has been reported by other investigators [29].

The ALT and AST values in haemodialysis patients are reported to be lower than in healthy individuals [30-

Table 2. Prevalence of HCV RNA and HCV genotypes in anti-HCV-positive haemodialysis patients in Jordan

\begin{tabular}{|c|c|c|c|c|c|c|}
\hline \multirow[b]{3}{*}{ Haemodialysis units } & \multicolumn{6}{|c|}{ Number $(\%)$ of patients } \\
\hline & \multirow[b]{2}{*}{ Total } & \multirow[b]{2}{*}{ Anti-HCV-positive } & \multirow[b]{2}{*}{ HCV RNA-positive } & \multicolumn{3}{|c|}{ HCV genotypes ( $\%$ of RNA-positive) } \\
\hline & & & & $1 \mathrm{a}$ & $1 b$ & 4 \\
\hline 1. Princess Basma Hospital & 65 & $23(35.4)$ & $7(30.4)$ & $2(28.5)$ & $1(14.3)$ & $4(57)$ \\
\hline 2. Jarash Government Hospital & 22 & $3(13.6)$ & $0(0)$ & $0(0)$ & $0(0)$ & $0(0)$ \\
\hline 3. Al-Salt Government Hospital & 38 & $12(31.6)$ & $5(41.6)$ & $3(60)$ & $2(40)$ & $0(0)$ \\
\hline 4. Al-Basheer Hospital & 70 & $22(31.4)$ & $7(31.8)$ & $4(57)$ & $2(28.5)$ & $1(14.2)$ \\
\hline 5. Al-Nadeem Hospital & 21 & $6(28.6)$ & $0(0)$ & $0(0)$ & $0(0)$ & $0(0)$ \\
\hline 6. Zarqa Government Hospital & 68 & $32(47.1)$ & $11(34.4)$ & $3(27.3)$ & $5(45.4)$ & $3(27.3)$ \\
\hline Total & 283 & 98 (34.6) & $30(30.6)$ & $12(40)$ & $10(33.3)$ & $8(26.6)$ \\
\hline
\end{tabular}


32]. In the present study, most anti-HCV-positive patients had ALT and AST values within the normal range, indicating that transaminases are not sensitive markers for ongoing HCV replication in haemodialysis patients. Similar results have been reported by others [5]. The elevated level of transaminases observed in some antiHCV-negative patients (Table 1) could be due to other factors including drugs or other viral agents.

The prevalence of anti-HCV in Jordanian haemodialysis patients was correlated with history of blood transfusion before the introduction of anti-HCV screening for Jordanian blood banks in 1993, suggesting this as an important route of infection. The seropositivity to $\mathrm{HCV}$ also increased significantly with increase in the duration of haemodialysis (Table 1), suggesting possible nosocomial transmission between patients. $\mathrm{Nu}-$ merous studies in recent years have provided molecular evidence for the nosocomial transmission of $\mathrm{HCV}$ within haemodialysis units $[3,4]$. The greatest risk of transmission of $\mathrm{HCV}$ within dialysis units is via dialysis next to an HCV-positive patient [33]. In the present study, the route by which the haemodialysis patients acquired $\mathrm{HCV}$ was not determined. All Jordanian haemodialysis units use hypex and formalin to disinfect the haemodialysis machines at the end of each session. Filters and tubes are discarded after each use. Nurses do not regularly wear gloves when dealing with patients. The hands of dialysis personnel have been implicated as a potential mode of facilitating transmission of HCV between haemodialysis patients [34]. Furthermore, variations in the level of hygienic standards may explain the differences in prevalence of anti-HCV positivity among the dialysis units (Table 2). To limit the spread of HCV infection in haemodialysis units, precautionary aseptic measures should be improved. Anti-HCV-positive patients should be considered potentially infectious and should be isolated from the anti-HCV-negative patients - dialysing HCVpositive patients in a separate unit or in a defined sector of a dialysis unit significantly reduces nosocomial HCV infection [33]. Furthermore, education programmes for staff on the risk of transmission of blood-borne viruses should be considered.

$\mathrm{HCV}$ genotype 1a is the most prevalent genotype in Jordanian patients (Table 2). This genotype is also predominant in Jordanian blood donors (unpublished data) and in haemodialysis patients of some Middle Eastern countries including Lebanon, Turkey, Cyprus [11] and Syria [18]. In contrast, HCV genotype 4 is the most prevalent genotype in other Middle Eastern countries including Saudi Arabia, Egypt, Yemen and Bahrain [11, 15, 36, 35].

The prevalence of antibodies to different HCV antigens in patients infected with genotype 4 was significantly lower than in patients infected with genotype 1 . The difference in this serological response may be due to differences in virus replication capacities or in the immune response to viral antigens, or to the presence of different epitopes in the two genotypes. Genotype dependence of antibody to HCV core, NS3 and NS4 antigens has been reported by others [36, 37].

We thank Miss Khitam Salem for technical assistance and Miss Dua' Salah Nazzal for assistance in the statistical analysis and typing of the manuscript. The research was made possible by a grant from the Higher Council and Science Technology in Jordan.

\section{References}

1. Sheu J-C, Lee S-H, Wang J-T, Shih L-N, Wang T-H, Chen D-S. Prevalence of anti-HCV and HCV viremia in hemodialysis patients in Taiwan. J Med Virol 1992; 37: 108-112.

2. Barton EN, King SD, Douglas LL. The seroprevalence of hepatitis and retroviral infection in Jamaica haemodialysis patients. West Indian Med J 1998; 47: 105-107.

3. Izopet J, Pasquier C, Sandres K, Puel J, Rostaing L. Molecular evidence for nosocomial transmission of hepatitis $\mathrm{C}$ virus in a French hemodialysis unit. J Med Virol 1999; 58: 139-144.

4. Abacioglu YH, Bacaksiz F, Bahar IH, Simmonds P. Molecular evidence for nosocomial transmission of hepatitis $\mathrm{C}$ virus in a haemodialysis unit. Eur J Clin Microbiol Infect Dis 2000; 19: $182-186$.

5. Yuki N, Ishida $\mathrm{H}$, Inoue $\mathrm{T}$ et al. Reappraisal of biochemical hepatitis C activity in hemodialysis patients. J Clin Gastroenterol 2000; 30: 187-194.

6. Young KKY, Resnick RM, Myers TW. Detection of hepatitis C virus RNA by combined reverse transcription-polymerase chain reaction assay. $J$ Clin Microbiol 1993; 31: 882-886.

7. Galan F, Perz-Gracia MT, Lozano A, Benavides B, FernandezRuiz E, Rodriguez-Iglesias MA. A 3-year follow up of HCVRNA viraemia in haemodialysis patients. Nephrol Dial Transplant 1998; 13: 1211-1214.

8. Simmonds P, Alberti A, Alter HJ et al. A proposed system for the nomenclature of hepatitis $\mathrm{C}$ viral genotypes. Hepatology 1994; 19: 1321-1324.

9. Tokita $\mathrm{H}$, Okamoto $\mathrm{H}$, Tsuda $\mathrm{F}$ et al. Hepatitis $\mathrm{C}$ virus variants from Vietnam are classifiable into the seventh, eighth and ninth major genetic groups. Proc Natl Acad Sci USA 1994; 91: $11022-11026$

10. Tokita $\mathrm{H}$, Okamoto $\mathrm{H}$, Iizuka $\mathrm{H}$ et al. Hepatitis $\mathrm{C}$ virus variants from Jakarta, Indonesia classifiable into novel genotypes in the second (2e and 2f), tenth (10a) and eleventh (11a) genetic groups. J Gen Virol 1996; 77: 293-301.

11. Dusheiko G, Schmilovitz-Weiss H, Brown D et al. Hepatitis C virus genotypes: an investigation of type-specific differences in geographic origin and disease. Hepatology 1994; 19: 13-18.

12. Bosmans JL, Nouwen EJ, Behets G et al. Prevalence and clinical expression of HCV-genotypes in haemodialysis patients of two geographically remote countries: Belgium and SaudiArabia. Clin Nephrol 1997; 47: 256-262.

13. McOmish F, Yap PL, Dow BC et al. Geographical distribution of hepatitis $\mathrm{C}$ virus genotypes in blood donors: an international collaborative study. J Clin Microbiol 1994; 32: 884-892.

14. Chan S-W, McOmish F, Holmes EC et al. Analysis of a new hepatitis $\mathrm{C}$ virus type and its phylogenetic relationship to existing variants. J Gen Virol 1992; 73: 1131-1141.

15. Davidson F, Simmonds P, Ferguson JC et al. Survey of major genotypes and subtypes of hepatitis $\mathrm{C}$ virus using RFLP of sequences amplified from the $5^{\prime}$ non-coding region. $J$ Gen Virol 1995; 76: 1197-1204.

16. Ayoola EA, Huraib S, Arif $\mathrm{M}$ et al. Prevalence and significance of antibodies to hepatitis $\mathrm{C}$ virus among Saudi haemodialysis patients. J Med Virol 1991; 35: 155-159.

17. Hmida S, Mojaat N, Chanouchi E et al. [HCV antibodies in haemodialysis patients in Tunisia.] Anticorps anti-HCV chez les hemodialysis en Tunisie. PathoBiol 1995; 43: 581-583.

18. Abdulkarim AS, Zein NN, Germer JJ et al. Hepatitis C virus genotypes and hepatitis $G$ virus in hemodialysis patients from Syria: identification of two novel hepatitis C virus subtypes. Am J Trop Med Hyg 1998; 59: 571-576.

19. Umlauft F, Gruenewald K, Weiss G et al. Patterns of hepatitis $\mathrm{C}$ viremia in patients receiving hemodialysis. Am $J$ Gastroenterol 1997; 92: 73-78. 
20. Dussol B, de Lamballerie X, Brunet $\mathrm{P}$ et al. Is hepatitis $\mathrm{C}$ virus-RNA detection by nested polymerase chain reaction clinically relevant in hemodialysis patients? Clin Nephrol 1996; 45: $257-260$

21. Fabrizi F, Martin P, Dixit V et al. Biological dynamics of viral load in hemodialysis patients with hepatitis $\mathrm{C}$ virus. $\mathrm{Am} \mathrm{J}$ Kidney Dis 2000; 35: 122-129.

22. Fabrizi F, Martin P, Dixit V et al. Quantitative assessment of HCV load in chronic hemodialysis patients: a cross-sectional survey. Nephron 1998; 80: 424-433.

23. Garinis G, Spanakis N, Theodorou V et al. Comparison of the enzyme-linked immunosorbant assay III, recombinant immunoblot third generation assay, and polymerase chain reaction method in the detection of hepatitis $\mathrm{C}$ virus infection in haemodialysis patients. J Clin Lab Anal 1999; 13: 122-125.

24. Furusyo N, Hayashi J, Ariyama I et al. Maintenance hemodialysis decreases serum hepatitis $\mathrm{C}$ virus (HCV) RNA levels in hemodialysis patients with chronic HCV infection. Am J Gastroenterol 2000; 95: 490-496.

25. Francois M, Dubois F, Brand D et al. Prevalence and significance of hepatitis $\mathrm{C}$ virus (HCV) viraemia in $\mathrm{HCV}$ antibody-positive subjects from various populations. $J$ Clin Microbiol 1993; 31: 1189-1193.

26. Marin MG, Bresciani S, Puoti M et al. Clinical significance of serum hepatitis $\mathrm{C}$ virus (HCV) RNA as marker of HCV infection. J Clin Microbiol 1994; 32: 3008-3012.

27. Tong CYW, Codd AA. Riba-2 band intensity and PCR in HCV infection. Lancet 1992; 340: 117.

28. Martinot-Peignoux M, Marcellin P, Xu L-Z et al. Reactivity to 33c antigen as a marker of hepatitis $\mathrm{C}$ virus multiplication. $J$ Infect Dis 1992; 165: 595-596.

29. Dubois F, Barin F, Goudeau A. [Anti-HCV serology for screening, diagnosis and surveillance of hepatitis C: role of the immunoblot.] Ann Biol Clin 1998; 56: 417-426.

30. Guh J-Y, Lai Y-H, Yang C-Y et al. Impact of decreased serum transaminase levels on the evaluation of viral hepatitis in hemodialysis patients. Nephron 1995; 69: 459-465.

31. Espinosa M, Martin-Malo A, Alvarez de Lara MA, Soriano S, Al Jama P. High ALT levels predict viremia in anti-HCVpositive HD patients if a modified normal range of ALT is applied. Clin Nephrol 2000; 54: 151-156.

32. Chimata M, Masaoka H, Fujimaki $\mathrm{M}$ et al. Low serum aminotransferase activity in patients undergoing regular hemodialysis. Nippon Jinzo Gakkai Shi 1994; 36: 389-395.

33. Wreghitt TG. Blood-borne virus infections in dialysis units a review. Rev Med Virol 1999; 9: 101-109.

34. Alfurayh O, Sabeel A, Al Ahdal MN et al. Hand contamination with hepatitis $\mathrm{C}$ virus in staff looking after hepatitis C-positive hemodialysis patients. Am J Nephrol 2000; 20: 103-106.

35. Scott DA, Constatine NT, Callahan J et al. The epidemiology of hepatitis C virus antibody in Yemen. Am J Trop Med Hyg 1992; 46: 63-68.

36. Fabrizi F, Lunghi G, Pagliari B et al. Molecular epidemiology of hepatitis $\mathrm{C}$ virus infection in dialysis patients. Nephron 1997; 77: 190-196.

37. Alonso C, Qu D, Lamelin JP et al. Serological responses to different genotypes of hepatitis $\mathrm{C}$ virus in France. J Clin Microbiol 1994; 32: 211-212. 